\title{
KATEGESE AS OUERPLIG EN AMPTELIKE KERKWERK
}

PROF. DR. J. I. DE WET

Die tema soos hierbo aangekondig, stel 3 vrae aan die orde te wete:

(a) Wat is kategese on is dit noodsaaklike kerkwerk?

(b) Is kategese ouerplig en amptelike kerkwerlk?

(c) Indien wel: wat is die verhouding tussen ouerplig en amptelike kerkwerk?

\section{A. WAT IS KATEGESE EN IS DIT 'N NOODSAAKLIKE KERK- WERK?}

Kategese is 'n onmisbare lewensfunksie van die kerk. Daarom is dit vir die kerk nodig om voortdurend nie net oor die kategese te besin nie, maar om ook die kategetiese arbeid te verrig. Dat ciit so is sal ons gaandeweg probeer aantoon.

Dic vraag of kategese ouerplig en amptelike kerkwerk is, is kennelik 'n vraag wat 'n spesifieke verband met die praktyk van dic kinderdoop hou. Dit is daarom ook 'n vraag wat binne dic Nederduitsch Hervormde Kerk gevra kan en moet word omdat die kerk se doopsbediening vir bykans die volle 100 persent aan kinders geskied.

(Kategese is egter ook n' kersteningswerk. Aangesien ons egter nou net die oog op ons eie kerklike situasia het sal dit miskien goed wees as hierdie vergadering by 'n latere geleentheid aandag kan gee aan die plek en taak van die kategese in die kerk se kersteningswerk.)

Ons wil begin deur die kategese as dooponderrig te kwalifiseer. Die rede vir hierdie omskrywing vind ons in die formulier vir die bediening van die doop aan die kinders van die gelowiges. Die formulier eis naamlik, „En die ouers sal verplig wees om hulle kinders as hulle opgroei hieromtrent breedvoeriger te onderrig." Voorlopig gaan dit vir ons nog nie om die ouers nie, maar om die verpligte onderrig op grond van die doop. Ook die ongebruikte katkisasieboek, Die Belydenis van die Hervormers," verstaan kategese as dooponderrig. Dié geskrif begin die katkisasie met 'n vraag aan die katkisant: Waarom wil jy katkiseer? Daarop laat dit die katkisant antwoord: Omdat ek my doop wil verstaan!

Ons kan dus goedskiks aanneem dat dis kategese tenminste enersyds dooponderrig is. Hierdie tipering bied vir ons 'n bruikbare aanvangspunt vir ons ondersoek cn beantwoording van die gestelde problematiek. Ons wil dus probeer om die gestelde vraag te beantwoord deur 'n paar aspekte van die doop nader te betrag. 


\section{Die DOOPFORMULE:}

In die tyd van die Nuwe Testament was daar blykbaar nie net een vasgestelde doopformule in gebruik nie. Ons vind in die Nuwe Testament uitdrukkings soos „epi to onomati Jesou Christou" (Hand 2:39), ,eis to onoma tou kuriou Jesou" (Hand. 8:16 en 19:5), ,en to onomati Jesou Christou," (Hand. 10:48) en dan nog die trinitariese, ,eis to onoma tou patros, kai tou huiou kai tou hagion pneumatos." (Matt. 28:19).

Die grootste gemene deler van die formules is die woord „onoma”. Die doop „op”, ,in” en „tot” die Naam bring egter almal presies dieselfde werklikheid tot uitdrukking „Eis to onoma", bring tot uitdrukking dat die dopeling hom ,gaan of laat rangskik" onder die persoonlike hoof tot wie se naam hy gedoop is d.i. Jesus Christus (vgl. P. J. Muller, Dogmatiek, bls. 250). Met ,epi" en „en" plus die datief word plek of die grond van 'n saak aangedui. Dit beteken dat die doop „op" of ,in" die Naam van Jesus Christus die dopeling op 'n bepaalde wyse ten opsigte van Jesus Christus „lokaliseer". Die doop ,lokaliseer" die dopeling ten opsigte van Jesus só, dat hy daar te staan kom waar sy verhouding tot die persoonlike Hoof, Jesus Christus, die sin en draende grond van sy lewe is, omdat hierdie persoonlike Hoof oor sy lewe heerskappy voer. Die trinitariese doopformule stel nie 'n ander saak teenoor dié van die enkelvoudige formules nie. Dit gee alleen 'n vollediger omskrywing van die feit dat die heil van die drie-enige God in die doop toegesê en verseël word.

Die Heer tot wie die doop die dopeling in 'n persoonlike betrekking plaas, is Jesus Christus wat gesterf en opgestaan het. Daarom moet ons ook net kortliks handel oor

\section{DOOP, DOOD EN OPSTANDING:}

Die predikoop wat in hierdie verband van besondere belang is, is Rom. 6:3-11. Paulus stel naamlik as 'n feit dat dié wat gedoop is, die sonde afgesterf het. Daarom dui hy die doop aan as 'n doop in die dood van Jesus Christus. Daar is naamlik 'n verband tussen die dood van Jesus Christus en ons sonde. Die clood is die straf op die sonde. Deur Sy dood dra Hy die straf cp ons sonde ephapaks. Dit is die plaasbekledende lyding. Paulus sien die saak dus so, dat ons deur die doop só tot Jesus Christus in relasie gestel word, dat sy dood beteken dat ons werklik die sonde afsterf. Die doop herhaal nie sy dood nie, maar lyf ons in sy dood in, sodat ons deur die doop saam met Hom op Golgota ons oue mens afsterf om saam met Hom in die opstanding met die nuwe mens oorklee te word. 
Die dood kon Hom egter nie hou nie. En by sy opstanding breek sy oorwinning oor sonde en dood finaal deur. Dan verklaar Paulus, dat, omdat die dood nie oor Hom heers nie, Hy sy lewe as 'n lewe vir God leef. Deur die doop word ons dus só in relasie tot Jesus Christus gestel dat ons nie net eenmaal aan die einde van die tyd weer verheerlik sal opstaan nie, maar nou-al in die nuwigheid van die lewe vir God kan wandel. „So moet julle (gedooptes) ook reken dat julle wel vir die sonde dood is, maar lewend is vir God in Christus Jesus onse Here."

Romeine 6 betuig die doop aan ons op so 'n wyse dat die heerskap van Christus oor ons lewe, ons hele lewe te staan laat kom onder die versoening deur sy bloed en die wedergeboorte deur sy Gees. Die dopeling word dus deur die doop uit die onversoende en onwedergebore sondaarsyn nuutgebore as kind van God in die lewe vir God. N.B. Daarom moet ons met nadruk verklaar dat die doop nie die einde van die pad is nie (Soos sommige mense skynbaar dink nie). Dit is in die volle werklike sin van die woord, die begin van die lewe in die gemeenskap met God. In die verband val te verstaan dat die doop alleen sin het vir die lewendes en nie vir sterwendes nie.

Voorlopig opsommend kan ons dus sê dat die doop ons in die relasie van verlostes tot Verlosser teenoor Jesus Christus stel. Dit is in die Ryk van die genade wat deur die mens nie anders ontvang kan word as deur die geloof nie en nie anders in die mens se lewe tot uitdrukking kan kom as deur die lewe uit die geloof nie. Daarom is dit ook nodig om nog verder die lig te laat val op doop en geloof en doop en bekering.

\section{DOOP EN GELOOF:}

Oor hierdie saak hoef nie breed uitgewei te word nie. Dit is immers die uitdruklike veronderstelling van die hele Nuwe Testament dat almal wat gedoop is, in die geloof in Jesus Christus moet volhard (vgl. byvoorbeeld Gal. 3:24-27). Ook van die volwassenes wat tot geloof gekom het en gedoop is, is dit sonder. meer veronderstel dat hulle in die geloof moet bly anders sou Demas se optrede byvoorbeeld sekerlik nie so 'n smartlike belewenis vir Paulus gewees het nie.

Ons wil hier volstaan met die slotsom waartoe Cullman gekom het na 'n eksegetiese ondersoek van die Nuwe Testament oor die verhouding van doop en geloof. Cullman verklaar:

1. ,... nach der Taufe ist der Glaube eine Forderung an alle Getauften. 
2. vor der Taufe ist die Bekundung des Glaubens zum zeichen cies göttlichen Willens, dass die Kirche die Taufe vornehme, eine Forderung an die Erwachsenen, die individuele vom Judentum oder, Heidentum kommen; in anderen fällen fehlt sie.

3. Während des Taufaktes ist der glaube eine Forderung an die betende Gemeinde (vgl. Tauflehre des neuen Testaments S. 49).

Punt 1 (en 3) is vir ons doeleindes hier tersake. Dit beteken dat ons op grond van die Nuwe Testament geregverdig is om te verklaar dat die kinderdoop soos dit in ons Kerk beoefen word, 'n doop tot geloof is. Beter gestel: Dit is die aanvang van die bemoeienis met die kinders van die gelowiges, sodat ook hulle die saligmakende geloof in Jesus Christus sal ontvang. Daarom moet dit gestel word dat wie ookal gedoop is op grond van die doop geroep is om te glo en in die geloof alles wat in die doop aan hom belowe en verseël is te aanvaar en in sy lewe te verwesenlik. Dit kom tot uitdrukking in die openbare belydenis van die geloof.

\section{DOOP EN BEKERING:}

In die nuwe Testament wor $\mathrm{J}$ sowel die Johannes-doop (byvoorbeeld Mk. 1:4) as die christelike doop (Hand. 2:38) aan die bekering verbind. Hierdie verbinding is in verband met ons probleem van groot gewig. Dit gaan vir ons hier egter nie oor cie vraag of geloof en bekering as menslike prestasies aan die doop vooraf moet gaan soos die grootdopers eis nie. Want ons insiens staan die goeie reg van die kinderdoop op bybelse gronde vas (vgl. J. I. de Wet, Kerklike Verkondiging in die huidige Tydsgewrig, bls 62-65).

Waarom dit vir ons hier gaan is naamlik die nuwe lewe as 'n lewe vir God. Hierdie lewe wat bestaan uit die berouvolle aflê van die sonde en die dankbare vlug na God en elke menslike poging om nie net volgens sommige nie, maar volgens al die gebooie van God te lewe, is eintlik die nuwe lewe wat 'n lewe vir God is. Wie dus die kinderdoop aanvaar en beoefen, aanvaar en beoefen dit as 'n doop tot bekering. Wie gevolglik as kind die doop ontvang het, het dit ontvang as die doop tot bekering. Soos wat hy kragtens sy doop geroep is tot die geloof in Jesus Christus so is hy kragtens sy doop verplig tot die daaglikse bekering van harte. Sy doop is vir hom die aanvangspunt van sy bekering as voortdurende beweging na God toe tot vermeerdering van Gods lof in die wêreld. 
Ons kan nou vasstel dat die doop wat ons in die heilsrelasie tot Jesus Christus stel juis só is, dat dit om daardie rede die gedooptes onder die noodsaaklikheid plaas om te glo en om 'n christelike lewe te lei.

Hierby is dit onvermydelik en gebiedend noodsaaklik om ladelik te stel dat die mens nie uit homself, nie uit eie krag of skerpsinnigheid of voortreflikheid kan glo of 'n christelike lewe kan lei nie. God self skenk deur sy Woord en Gees geloof en die moontlikheid tot 'n lewe uit die geloof. Dit staan bo alle twyfel vas. Verder het dit Hom behaag om deur die doelbewuste en ropsetlike oordrag van die evangelie wat $\mathrm{Hy}$ aan sy Kerk opgedra het, die geloof en die christelike lewe deur sy Woord en Gees te stig en instand te hou. Die doelbewuste en opsetlike oordrag van die evangelie onder Gods opdrag aan die opkomende geslag ter wille van hulle geloof en hulle christelike lewenswandel is die Kategese. (Artikel 90 van die bepalings van die Kerkwet stel dit ook uitdruklik só). Dit het ons insiens ook duidelik genoeg geblyk dat juis die kinderdoop kategese as 'n onvermydelike lewensfunksie aan die Kerk oplê.

\section{B. IS KATEGESE OUERPLIG EN AMPTELIKE KERWERK? \\ I. INLEIDING:}

Die vraag wat hier aan die orde kom is naamlik die vraag na wie hierdie vir die Kerk lewensnoodsaaklike kategese moet behartig. Die ondersoek na hierdie vraag is terselfdertyd 'n ondersoek na die gronde waarop die Kerkwet staan, wanneer daarin bepaal word dat die kategese ,deur die ouers" en ,in die daartoe bestaande katkisasieklasse" waargeneem moet word. Ook hierdie vraag wil ons probeer beantwoord aan die hand van 'n toeligting op enkele aspekte van die doop.

\section{DOOP EN VERBOND:}

Ons wil hoegenaamd nie probeer om die verhouding van doop en verbond volledig hier te behandel nie. Eintlik wil ons net die aandag bepaal by een besondere aspek van die verbond wat hier vir ons van deurslaggewende betekenis is.

Kortweg kan verbond gedefinieer word as "God se genadige toeweiding tot sy mense" (K. Bijlsma, Doop in het pastoraat, bls. 36). In die lig hiervan wil ons stel dat al het die uiterlike gedaante van die Ou Verbond verbygegaan, dan het die innerlike werklikheid, daarvan onveranderd gebly. Daarom geld die inhoudelike gegewens van die Ou Testament insake die verbond vandag nog vir ons. 
Die saak wat nou vir ons van groot belang is, is die kwessie van die eenheid van die gesin. Binne die raamwerk van die Verbond is die gesin egter nie net 'n gewone eenheid vanweë die bloedband wat hulle onderling aan mekaar verbind nie. Vanweë die feit dat die indiwiduele lede die teken van die opname in die verbond ontvang het, word die gesin eintlik communio sanctorus in die kleine - 'n huis-gemeente as't ware.

Presies hoe omvattend hierdie verbondsgedagte van die huisgesin as eenheid werklik was, bly byvoorbeeld duidelik uit die joodse proselite-praktyk en die gesinsdope waarvan die Nuwe Testament melding maak. Oorgang van die ouer na die Jodedom of Christendom was genoegsame grond om die gesinslede deur uitdeling van die verbondsteken saam in die verbond te laat opneem (vgl. Hand. 16).

Watter implikasies die verbondsgedagte van die eenheid van die gesin vir ons onderhawige vraagstuk het blyk duidelik byvoorbeeld uit die uitspraak van 1 Kor. 7:14 waar gestel word dat die ongelowige eggenoot deur die geloof van die gelowige geheilig word en dat selfs die kinders uit so 'n meng-huwelik geheilig is. Hierdie heiliging van die gesinslede beteken eintlik niks anders as dat hulle deur die geloof van die gelowige ge. sinslid vir God opgeroep en aangespreek word nie. Dit spreek dus eintlik vanself dat die gelowige in hierdie oproep en aanspreek van sy gesinslede vir God nie passief nie, maar aktiewe instrument moet wees. Hy is immers deur sy geloof daartoe verplig.

In die lig hiervan moet die mededeling dat die sipier van Filippi „panoikei” bly was dat hy tot geloof gekom het (Hand. 16:33 en 34) gewaardeer word. Ook Hand. 2:39 waar betoog word dat die verbondsbeloftes vir ouers en kinders is, kry in hierdie kader sy volle draagkrag. Juis in die raamwerk van die verbond en in verband met hierdie besondere visie of gesinseenheid en gesinsheiliging, kry die medeverantwoordelikheid van die gesinslede vir mekaar se geloof en lewe as verbondbegunstigdes so 'n diepte en 'n omvang dat dit nie sonder straf versuim en nagelaat kan word nie.

As hierby verder ingedagte gehou word dat die ouers self hulle kinders voor doop hou en dat dit van die vroegste tye af gebruik was dat die ouers vir die kinders op die doopvrae moes antwoord as die kinders self te klein was, dan geld die woorde van Deut. 4:9 en 6:6 en 7 as die vasstelling van die noodwendige gedragslyn van die ouers teenoor die kinders binne die opset van die verbond. Vanweë die duidelikheid haal ons dié twee uitsprake hier woordeliks aan: 
„Neem jou net in ag en wees terdeë op jou hoede, dat jy die dinge nie vergeet wat jou oë gesien het nie, en dat hulle nie uit jou hart wyk al die dae van jou lewe nie; en jy moet dit aan jou kinders en aan jou kindskinders bekend maak."

„En hierdie woorde wat ek jou vandag beveel, moet in jou hart wees; en jy moet dit jou kinders inskerp en daaroor spreek as jy in jou huis sit en as jy op pad is en as jy gaan lê en as jy opstaan."

Kragtens die genadeverbond is die ouers dus verplig om doelbewus en opsetlik deur oordrag van die verbondswoorde (evangelie), besig te wees met hulle kinders ter wille van die kinders se geloof. Die doopformulier maak dus met goeie reg van die ouers kategete in die frontlinie van die Kerk se kategetiese arbeid. Kategese as ouerplig is dus eintlik 'n saak van gehoorsaamheid en diensbetoon aan die God van die verbond.

\section{DOOP EN KERK:}

Die eerste saak wat ons hier moet duidelik stel is naamlik dat kategese wat deur die ouers behartig word sondermeer kerkwerk is. 'n Mens kry soms die indruk dat die ouers se kategetiese bemoeienis nie as kerkwerk beskou word nie. Sover ons kennis strek is daar geen handboek oor die kategese wat enige aandag gee aan die kategese as ouerplig nie. In ons eie Kerk lyk dit soms ook of daar mense is wat die kategese bloot as 'n amptelike kerkwerk wat in die Sondagskool plaasvind, beskou. Hierteenoor wil ons stel dat kategese as ouerplig wel deeglik kerkwerk is, want die ouers doen dit tog mos as gelowiges, dit wil sê as Kerk van Jesus Christus.

Die vraag is dus nie of die kategese kerkwerk is nie, maar of dit bo- en behalwe ouerplig ook nog amptelike kerkwerk is. Hieroor moet twee sake gestel word naamlik:

(a) Doop is opname in die kerk. I Kor. 12:13 stel dit baie duidelik „Want ons is almal ook deur een Gees gedoop tot een liggaam ..." Opvallend is dat Paulus die ..hen soma", as aanduiding van die gemeente gewoonlik in verband met die sakramente gebruik (vgl. 1 Kor. 10:17 byvoorbeeld). Aangesien die doop opname in die gemeente is, moet ons saam met Cullmann stem dat die doop gevolglik 'n gebeurtenis aan en met die liggaam van Christus is.

(b) Die doop moet amptelik bedien word. Dat die doopsbediening wat aan die kerk opgedra is, amptelik, dit wil sê deur ampsdraers wat daartoe geroep is moet plaasvind, spreek duide- 
lik uit Matt. 28:19 en die talle vermeldings van doopsbedienings deur wettige ampsdraers in die Nuwe Testament. Die mense aan wie die doopopdrag oorspronklik gegee is, was tenminste almal ampsdraers. So is die mense van wie genoem word dat hulle die doop bedien het ampsdraers. (Soos Filippus, Petrus en Paulus).

In verband met hierdie twee sake wat genoem is geld die opdrag van Matt. 28:19 „... en leer hulle om alles te onderhou wat Ek julle beveel het," as 'n baie belangrike uitspraak. Die doop wat amptelik bedien is, sodat daardeur iets met die gemeente van die Here sou gebeur, wil opgevolg word. Hierdie gedooptes moet naamlik geleer word. Didaskein in die Nuwe Testament beteken eintlik die saaklike blootlegging van die diepste $\sin$ en betekenis van die evangelie tot opbouing van die gemeente in die allerheiligste geloof. Die ampsdraers het ook die opdrag om die gedooptes so te leer. Didaskein is egter 'n omvattende aanduiding van die binnegemeentelike leerwerksaamheid. Al kan ons dus nie sê dat die leeropdrag net die kategese spesifiek aandui nie, kan ons dan tog wel sê dat die kategese daarin opgeneem is. Die binnegemeentelike leeraktiwiteit tot opbou van die geloof is dus eintlik die raamwerk waarbinne die kategese as amptelike kerkwerk moet plaasvind.

Verder is dit in hierdie verband behartenswaardig om te let op die verbod wat die doopformulier op doop uit gewoonte of bygelowigheid lê. Ons het reeds ten oorvloede aangetoon dat die doop gevolg wil hê in die geloof en 'n christelike lewe. Veral die doop uit gewoonte sal dan beteken dat die doop wel ontvang word, sonder dat 'n vinger verroer word om die doop dié gevolg te laat vind wat dit wel wil hê. Dit wil sê oral waar daar gedoop word maar die kategetiese bemoeienis met die dopeling versuim of verwaarloos word, het ons dan te doen met 'n doop uit gewoonte. In die lig hiervan is dit duidelik dat ook die kerk nie uit gewoonte of bygelowiheid die doop mag bedien nie.

Kategese as amptelike kerkwerk is dus 'n saak van die hoogste verantwoordelikheid want die amptelike instansies sal op alle vlakke moet toesien dat die doop wat steeds amptelik bedien word, nie moet verval en vervlak tot 'n doop uit gewoonte of hygelowigheid nie. En dit opsig self is ook nog 'n kategetiese bemoeienis naamlik dat amptelik daarvoor gesorg moet word dat die doop sy gewilde gevolg verkry. Kategese is dus eintlik die enigste weermiddel teen die doop uit gewoonte.

Samevattend kan ons dus sê dat die Kerkwet op goeie teologiese gronde bepaal dat kategese ouerplig en amptelike kerkwerk moet wees. 


\section{WAT IS DIE VERHOUDING TUSSEN KATEGESE AS OUERPLIG EN AMPTELIKE KERKWERK?}

Die vraag wat hiermee aan die orde kom is naamlik hoe die derde doopvraag verstaan moet word. Die vraag vra naamlik dat die ouers hulle kinders na hulle vermoë moet onderrig of laat onderrig. Veral die woorde "of te laat onderrig" skep eintlik die probleme. Op die oog af lyk dit of hierdie toevoeging die moontlikheid dat die ouerplig heeltemal deur iemand anders oorgeneem kan word, oopmaak. Dan is hierdie vraag 'n absolute teenstelling met wat vroeër in die formulier beweer is naamlik dat die ouers verplig is om hulle kinders breedvoeriger te onderrig.

Daar is twee sake wat oorweging verdien:

(a) Die situasie ten tyde van die opstel van die formulier. Dit is naamlik ' $n$ bekende feit dat die Roomse kerk voor die kerkhervorming veral, geen besondere waarde aan die geletterdheid van die breë massa geheg het nie. Ook was daar destyds nie die onderwysgeriewe en moontlikhede van vandag nie. Die onvermydelike gevolg was dat baie mense nie kon lees en skryf nie. Gevolglik was hulle self nie baie goed daartoe in staat om hulle kinders uit die Bybel aangaande die geloof in Jesus Christus te onderlê nie. Aangesien die onmoontlike nie verwag kan word nie, is daar 'n konsessie gemaak sodat ouers die hulp van bevoegde mense kon inroep waar hulle self te kort geskiet het.

(b) Die tweede saak waarop gewys moet word is naamlik dat die derde vraag tog nie in stryd is met die vroeëre eis van die formulier nie. Die formulier eis naamlik dat die ouers hulle kinders breedvoeriger moet onderrig. Die klaarblyklike bedoeling daarvan is naamlik dat die ouer-onderrig meer omvat as wat die formulier self bevat. Daarmee word egter nog nie vereis dat die ouer self en alleen die volledigste moontlik dooponderrig sa! behartig nie. Geheel in lyn hiermee vereis die derde doopvraag dan ook net dat die ouer tot die maksimum van sy vermoë die dooponderrig sal behartig. Meer as dit kan tog nie verwag word nie.

Hieruit is egter ook duidelik dat die ouerplig nie heelemaal deur iemand anders oorgeneem kan word nie. Dat die ouer-arbeid egter aangevul kan word in die opsigte waarin dit te kort skiet, word wyd oopgelaat.

In die lig hiervan kan voorlopig gestel word dat die amptelike kategese wel die ouerwerk kan en moet aanvul in sovérre daarin tekorte voorkom. 
Die toevoeging en veral die woordjie "of" in die toevoeging tot die derde doopvraag het in die verlede al heftige diskussie uitgelok. In die lig van die saamgaan van ouerplig en amptelike kerkwerk is daar dan ookal voorgestel dat "of" met „en" vervang moet word. Dit deug egter ook nie, want dan word 'n relatiewe saak tot 'n absoluutheid verhef. Prinsipieel moet die moontlikheid oopgelaat word dat daar ouers is wat wel bekwaam is om huile kinders 'n volledige dooponderrig te gee. Hulle sal dus geen aanvulling nodig hê nie. Wat meer is: Dit is die eksplisiete bedoeling van die Skrif dat die lidmate gaandeweg deur die binnegemeentelike bearbeiding uiteindelik daartoe bekwaam moet word om andere en veral hulle kinders te onderrig (vgl. Heb. 5:12 en Ef. 4:11 en 12) aangaande die geloof.

Prakties sal die Kerk dus met die moontlikheid moet reken dat daar mense kan kom wat volledig toegerus is om belydenis van geloof te doen sonder dat hulle onder die amptelike kategese gekom het. Om sulke mense nie tot die belydenis van die geloof toe te laat nie, alvorens hulle nie 'n sekere aantal van die amptelike katkisasieklasse bygewoon het nie, lyk totaal verkeerd.

In die praktyk gebeur dit soms dat persone wat wel die amptelike katkisasie getrou bygewoon het maar selfde of nooit in die erediens gekom het of op geen wyse met die gemeente neegeleef het nie, tog tot belydenis toegelaat word. Ook dit is verkeerd! Wat hiermee bedoel word is dat al sou 'n persoon volledige dooponderrig tuis ontvang het, dan hef dit nog nie die amptelike kategetiese bemoeienis op nie. Die Kerkraad moet so 'n kandidaat nog ondersoek en toelaat tot belydenis. Hierdie ondersoek en toelating kan nie net ' $n$ kandidaat se kennis betref nie. Dit moet ook gaan oor die kandidaat se lewensvorming omdat die evangelie nie net uit die goddelike indikatief nie maar ook uit die goddelike imperatief bestaan.

Ons insiens moet die wisselwerking tussen ouerplig en amptelike kerkwerk nie net die leer en die lewe van die dopeling raak nie. Efesiërs 4:11 en 12 maak dit ook vir die Kerkraad onvermydelik om na die beste van sy vermoë die ouers toe te rus vir die nakoming van hulle kategetiese arbeid. 